\title{
Calculation of the Generalizing Indicator of Productivity of the Enterprises Activity Based on the Matrix-Rank Approach
}

\author{
Kavun Sergii ${ }^{1, *}$, Zhosan Ganna ${ }^{2}$ \\ ${ }^{1}$ Department of Information Technologies, Kharkiv Institute of Banking University of Banking of the National Bank of Ukraine (Kyiv), \\ Kharkiv, Ukraine \\ ${ }^{2}$ Management and Marketing Department, Kherson National Technical University, Kherson, Ukraine \\ *Corresponding author: kavserg@gmail.com
}

Received November 08, 2014; Revised November 27, 2014; Accepted November 30, 2014

\begin{abstract}
The method of calculation of a generalizing indicator of a productivity of the enterprise activity based on the matrix-rank approach is presented in this paper. The value of the generalizing indicator of productivity of any enterprise activity due to use of the geometrical interpretation can be defined based on the matrix-rank approach. Intermediate indicators of economic, ecological, social and legal components of productivity of the enterprise activity can be calculated with the help of the proposed method. Practical conclusions for rather real enterprises of the elected industry area can be formulated based on the calculated generalizing indicator of productivity of the enterprise activity.
\end{abstract}

Keywords: Productivity, Enterprise Activity, Economic, Ecological, Social, Legal Components, Matrix-Rank Approach, Enterprise Purposes

Cite This Article: Kavun Sergii, and Zhosan Ganna, "Calculation of the Generalizing Indicator of Productivity of the Enterprises Activity Based on the Matrix-Rank Approach." Journal of Finance and Economics, vol. 2, no. 6 (2014): 202-209. doi: 10.12691/jfe-2-6-1.

\section{Introduction}

Productivity of activity of some enterprises as the primary subject of the market is important for a number of reasons. Productivity of a branch and all economy in general in this separated sector of functioning consists of results of activity of many industrial enterprises. Therefore, this question has the general social and economic meaning for all society. Information on the results of the enterprise activity is important for all participants of external and internal business processes for further understanding of some prospects of its development and the solution of a question about continuation of further collaboration in one or another form and obtaining the incomes adequate to the expenses, or a satisfaction of some requirements.

Adhvaryu and Nyshadham, 2014 [1]. They have studied the role of household enterprise as a coping mechanism after health shocks. Using variation in the cost of traveling to formal sector health facilities to predict recovery from acute illness in Tanzania, they have shown that individuals with prolonged illness switch from farm labor to enterprise activity. This response occurs along both the extensive (entry) and intensive (capital stock and labor supply) margins. Family members who are not ill exhibit exactly the same pattern of responses. Deriving a simple extension to the canonical agricultural household model, we show that our results suggest complementarities in household labor.
Serba, 2011 [22]. He has shown in their paper classification of kinds of enterprise activity is given, manufacture factors are considered, the variant of calculation of requirement of the enterprise in financial assets is offered and productivity of industrial activity with reference to the enterprise business plan is estimated. The business plan - the short, exact, accessible and clear description of prospective business, the major tool by consideration of a considerable quantity of the various situations, allowing to choose the most perspective desirable result and to define means for its achievement. The business plan is the document, allowing operating business, therefore it is possible to present as the integral element of strategic planning and as a management for execution and control. It is important to consider the business plan as process of planning and the tool of intracompanies management.

Levchenko and Rudychev, 2013 [20]. They have presented the article is devoted to business activity study and its assessment within the industrial enterprise. Qualitative and quantitative indices characterizing business activity of the enterprises are described and proved in it. The technique of the complex assessment of business activity by determination of its level and calculation of the made coefficients is offered and approved. The coefficient of business activity is grouped and compared with a hierarchical scale. Recommendations for practical application of the technique for the assessment of business activity at the industrial enterprises are offered. 
Gornostaeva et al., 2014 [10]. These authors have develop the methodical aspects of analysis of efficiency of service enterprises activity, conducts analysis of efficiency of service enterprises activity in Russia and analysis of efficiency of service enterprises activity in the countries of Eastern Europe, and then makes out comparative analysis and provides recommendations upon development of service sector in Russia and the countries of Eastern Europe.

Grygorenko, 2001 [12]. Her paper investigates the impact of privatization on enterprises' financial and operating activity by conducting a comparative analysis between privatized and state-owned enterprises. Empirical research was based on a sample of 379 Ukrainian enterprises for the period of 1997-1999. Results of estimation have indicated that privatization positively influences labor productivity and profitability of enterprises. However, its results are not immediate they become evident over time. In order to tackle the problem of potential endogeneity, instrumental variables estimation technique is used. Instruments used are financial indicators of firms' activity, which, according to Ukrainian legislation, are the basis on which state authorities make decisions about the expediency of privatization.

Separated questions about studying and entity of the productivity of the enterprise activity were been shown in some publications by well-known authors (Korchevska, Zhosan and Kavun, 2013 [18]; Darmits, 2010 [4]; Druker, 2004 [7]; Davenport, 1913 [5]; Safin, 2009 [21], etc.). However, the problem of calculation of the generalizing indicator of productivity of an activity of any enterprises does not have any final solution; therefore, it requires the further improving.

Statement of the task. Will need to develop of the corresponded technique and calculation of the generalizing indicator of the productivity of enterprises activity in the elected branch on its basis.

\section{Description of the Proposed Method}

One of the main tasks of any enterprise is a productive activity, which sometimes interpreted as the functioning (but it is not an inconsistent question), which can be carried out only at coordinating the purposes and results with internal and external business processes and their participants. Productivity is defined not only by receiving a certain result at the achievement of some goals, and the rational using of the enterprise resources and the achievement of a specific goal. This pre-determines the using of the certain resources with certain their combination [7].

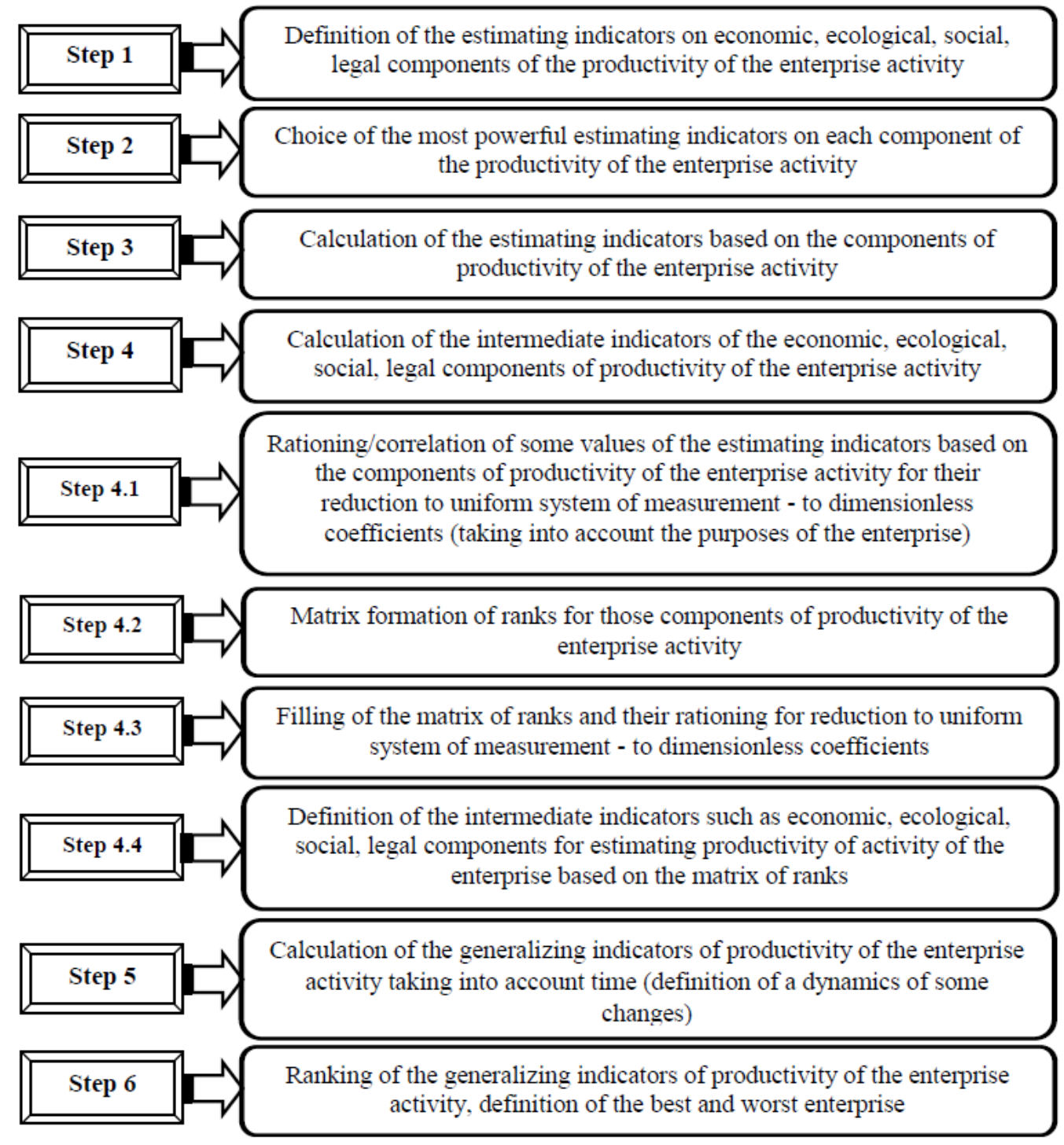

Figure 1. Scheme of the method of calculation of the generalizing indicators of productivity of the enterprise activity (author's development) 
The level of achievement of the objectives of the enterprise activity, which corresponds to the calculated indicator, has been proposed for better understanding by the authors. This level was presented with the help of quantitative and quality indicators, which characterize a compliance of some results of economic, ecological, social, legal components (number of these components, Ks $=4$ ) productivity of activity of the enterprise in relation to its purposes. In addition, this level can be saved up potential for further conducting and covering socially responsible business processes as the productivity of the industrial enterprise activity.

In this regard, the indicator of productivity of the industrial enterprise activity need to estimate for a satisfaction of multilateral interest in this problem. The corresponding technique (Figure 1) was proposed by the authors for solution of this question of an assessment of the productivity indicator of the industrial enterprise activity.

As a basis of this technique of an assessment of the productivity indicator of the industrial enterprise's activity there were used the following two approaches: the balanced scorecard for an assessment of the enterprise activity [2,13] and the matrix-rank approach $[14,15,16,17]$.
The indicator of productivity of the enterprise activity is defined based on the general indicators of the following four components: economic, ecological, social and legal. It allows considering most fully all fields of the industrial enterprise activity and its purposes [2].

The proposed technique of an assessment of productivity indicator of the industrial enterprise activity consists of the following steps.

Step 1. Calculation of the basic indicators of the enterprise activity, which are a basis for the next calculation of some intermediate indicators of the following components of productivity of the enterprise activity - economic, ecological, social and legal. Number of these indicators based on the purposes groups of the industrial enterprise should be selected for their further calculation.

Step 2. Number of the estimated indicators according to the chosen purposes groups of the industrial enterprises (Table 1) should be selected for further calculation of the intermediate indicators of the already chosen economic, ecological, social and legal components. The method of an expert assessment, which will allow allocating the five most important estimated indicators for each component of the productivity of the enterprise activity (Table 2), was applied to calculation of the most powerful chosen earlier indicators.

Table 1. Enterprise purposes for the chosen components of the productivity of the enterprise activity

\begin{tabular}{|c|c|}
\hline Components & Purposes \\
\hline The economic component & $\begin{array}{l}\text { Maximum use of fixed assets of the enterprise } \\
\text { The maximum sale of the developed production } \\
\text { Decrease in expenses } \\
\text { Increase in net profit } \\
\text { Financial independence }\end{array}$ \\
\hline The ecological component & $\begin{array}{l}\text { Decrease in volume of the rejected production } \\
\text { Increase of innovation of the equipment } \\
\text { Decrease in material expenses } \\
\text { Improvement of quality of production } \\
\text { Care of environment }\end{array}$ \\
\hline The social component & $\begin{array}{l}\text { Increase of labor productivity of workers } \\
\text { Decrease in turnover of staff } \\
\text { Motivation of workers } \\
\text { Decrease in expenses on a salary } \\
\text { Increase of return of a salary of workers }\end{array}$ \\
\hline The legal component & $\begin{array}{l}\text { Implementation of contractual obligations on quality of production } \\
\text { Decrease in number of judicial claims on the enterprise } \\
\text { Implementation of contractual obligations behind the product range } \\
\text { Reduction of losses from penalties } \\
\text { Implementation of all contractual obligations behind term }\end{array}$ \\
\hline
\end{tabular}

Table 2. List of the estimated indicators for a calculation of the generalizing indicator of the productivity of the enterprise activity

\begin{tabular}{|c|c|c|c|}
\hline Symbol & Name of an indicator & Symbol & Name of an indicator \\
\hline \multicolumn{2}{|r|}{ Economic component } & \multicolumn{2}{|r|}{ Ecological component } \\
\hline E1 & Capital productivity & Ec1 & Developed production rejected coefficient in a total amount \\
\hline E2 & Production profitability & Ec2 & Innovativeness equipment coefficient \\
\hline E3 & Expenses profitability & Ec3 & Part of the materials in the products cost \\
\hline E4 & Net profit growth coefficient & Ec4 & Improvement coefficient of the quality products \\
\hline E5 & Financial independence coefficient & Ec5 & Coefficient of decreasing in the penalties sum paid for the environmental pollution \\
\hline \multicolumn{2}{|r|}{ Social component } & \multicolumn{2}{|r|}{ Legal component } \\
\hline S1 & Labor productivity of workers & L1 & Percent of an implementation of the contractual obligations on a quality \\
\hline $\mathrm{S} 2$ & Profitability of a salary & L2 & Quality coefficient of the legal services \\
\hline S3 & Index of salary increase at the enterprise & L3 & Percent of an implementation of the contractual obligations on an assortment \\
\hline S4 & Return of the salary & L4 & Coefficient of the payment discipline \\
\hline S5 & Saving of the salary & L5 & Percent of an implementation of the contractual obligations by maturity \\
\hline
\end{tabular}

Step 3. Calculation of the estimated indicators of for the further calculation of the intermediate indicators of productivity of the enterprise activity, which are a basis economic, ecological, social and legal components. 
Step 4. Calculation of the intermediate indicators of economic, ecological, social and legal components of the productivity of the enterprise activity.

The matrix rank approach was used for a calculation of the intermediate indicators of some chosen earlier components of the productivity of an activity of the following enterprises: Enterprise 1; Enterprise 2; Enterprise 3; Enterprise 4; Enterprise 5; Enterprise 6 for 2009-2013. These enterprises were been depersonalized that those calculations will not influence to the real enterprises.

Step 4.1. We have carried out the rationing/correlation of the obtained values of the estimated indicators on some components of productivity of the enterprise activity to make them into uniform measurement system (for obtaining a possibility of the comparative analysis) as the dimensionless coefficients (taking into account the enterprise purposes).

Step 4.2-4.3. Formation of a matrix of the ranks for the chosen components of a productivity of the enterprise activity.

Considering the estimated indicators for a definition of the intermediate indicators for each component, the productivity of the enterprise activity was chosen proceeding from groups of the enterprise purposes. These purposes are equivalent within each component. Thus, the matrix of ranks can be proposed for calculation of the intermediate indicators of the introduced components.

The previous step 4.1 has allowed proposing the unified general range of values for each evaluated indicator in a range from 0 to 1 . Thus, the matrix of ranks can be built with a certain differentiation step depending on a quantity of the purposes of the enterprise activity, beginning from two purposes (in the simplest case). The matrix of ranks has been offered to present as the two-dimensional matrix with certain quantity of the lines and columns. In that case, to each indicator can be appropriated respectively two possible values $(\mathrm{S}=2)-0,5$ and 1 . Then a dimension $(N)$ of the matrix of ranks (Sample), if a quantity of the purposes will be divided (in our case, the quantity of those purposes is $K_{p}=5$ ) will equal to quantity of lines. For example, $S_{K P n u m b e r}=2$, and the quantity of columns is equal $\mathrm{S}_{\mathrm{KPcol}}=3$, then $\mathrm{N}=\mathrm{S}_{\mathrm{KPnumber}} \times \mathrm{S}_{\mathrm{KP} \text { col }}=\mathrm{S}\left({ }_{\text {KPnumber }}\right.$ KPcol $)=2_{2}$ $\times 2_{3}=32$. However, in this case, the accuracy of the calculation of the generalizing indicator of a productivity of the enterprise activity will be rather low, considering wide range of values of estimated indicators.

The matrix of ranks Sample (Table 3) with the determined earlier parameters $\left(S=2, S_{\text {KPnumber }}=2, S_{\text {KPcol }}\right.$ $=3$ ) has been presented for bigger convenience of an explanation of the matrix-rank approach using. However, the matrix of ranks with the differentiation step 0,1 ( $\mathrm{S}=$ 10) and the obtained dimension $\mathrm{N}=105=10000$ has been used for a calculation of the generalizing indicator of productivity of the real enterprises activity.

At first, the filling direction (growth or fall) of the ranks (i.e. their values) in this matrix is necessary to define for a formation of ranks in this matrix. This step is possible after titles formation (by vertical at $\mathrm{S}_{\mathrm{KPcol}}=3$ (in our case for an example), and by horizontal at $\left.S_{K P n u m b e r}=2\right)$. Then, it can be obtained in that case, when this value (minimum) corresponds by the left lower cell of a matrix having taken the minimum value (in our case it is 0,5 ) for all estimated indicators. We will be able to obtain the following case, when the maximum value (in our case it is 1) corresponds to the right top cell of a matrix by analogy. Thus, the direction of setting of ranks in a matrix can be defined. The matrix of ranks, which could be obtained in this case, is called the rectangular Toeplitz matrix or a diagonalconstant matrix [3,11]. In this matrix, the identical elements are located on all diagonals, which are parallel to the main diagonal (this is shown by gray color in Table 3).

Table 3. Matrix of ranks for calculation of the intermediate indicators of some components for a productivity of the enterprise activity (for $S=2, N=32$ )

\begin{tabular}{|c|c|c|c|c|c|c|c|c|c|c|}
\hline \multirow{2}{*}{\multicolumn{2}{|c|}{$\begin{array}{l}\mathrm{S}^{\mathrm{KP}}{ }_{\text {number }} \\
=2\end{array}$}} & \multicolumn{4}{|c|}{0,5} & \multicolumn{4}{|c|}{1} & \multirow{3}{*}{$\begin{array}{l}\mathrm{S}^{\mathrm{KP}}{ }_{\mathrm{col}} \\
=3\end{array}$} \\
\hline & & \multicolumn{2}{|c|}{0,5} & \multicolumn{2}{|c|}{1} & \multicolumn{2}{|c|}{0,5} & \multicolumn{2}{|c|}{1} & \\
\hline & & 0,5 & 1 & 0,5 & 1 & 0,5 & 1 & 0,5 & 1 & \\
\hline \multirow{2}{*}{1} & 1 & 16 & 21 & 26 & 31 & 36 & 41 & 46 & 51 & \\
\hline & 0,5 & 11 & $\overline{16}$ & 21 & 26 & 31 & 36 & 41 & 46 & \\
\hline \multirow{2}{*}{0,5} & 1 & 6 & 11 & 16 & 21 & 26 & 31 & 36 & 41 & \\
\hline & 0,5 & 1 & 6 & 11 & 16 & 21 & 26 & 31 & 36 & \\
\hline
\end{tabular}

Thus, a formation of ranks in this matrix can be initiated. Let us establish the minimum rank is 1 (but for a convenience the minimum rank can be equal to any initial value). Then the step can be equal five (a difference of the adjacent ranks), the ranks can be calculated based on this step (according to Table 1) and proceeding from a quantity of the estimated indicators by each component of a productivity of the enterprise activity. The determination order of the ranks, which are placed in the matrix's cells and which can be determined by the importance coefficient of the estimated indicators according to the enterprise purposes (according to Table 1). However, because in our case, the importance coefficients of the purposes $K_{p}=5$ by each component (their quantity equals 4, Table 1) are equivalent (i.e. they do not ranked). Therefore, the weights of the estimated indicators also are equivalent, i.e. the ranks in the matrix cells are distributed evenly by the direction of filling for the ranks (it will be a growth or fall of their values) in a matrix of ranks. In our case (Table 3), it will be from the left bottom corner (cell) to the right top corner (cell), i.e. by the directions of the main diagonal of a matrix (Table 3 ).

All values of the matrix of ranks should be normalized for bigger convenience of using of the intermediate indicators (from a point of view of an assessment of some economic indicators), as it is shown in Table 4.

Table 4. The normalized matrix of ranks calculation of the intermediate indicators of components of the productivity of the enterprise activity (it is also known as Toeplitz's matrix, according to property of a matrix; $\mathrm{S}=2$ )

\begin{tabular}{|c|c|c|c|c|c|c|c|c|c|}
\hline \multirow{3}{*}{\multicolumn{2}{|c|}{$\begin{array}{l}\text { Estimated } \\
\text { indicators }\end{array}$}} & \multicolumn{4}{|c|}{0,5} & \multicolumn{4}{|c|}{1} \\
\hline & & \multicolumn{2}{|c|}{0,5} & \multicolumn{2}{|c|}{1} & \multicolumn{2}{|c|}{0,5} & \multicolumn{2}{|c|}{1} \\
\hline & & 0,5 & 1 & 0,5 & 1 & 0,5 & 1 & 0,5 & 1 \\
\hline \multirow{2}{*}{1} & 1 & $\begin{array}{l}\hat{m} \\
\stackrel{n}{0} \\
\sigma^{\prime}\end{array}$ & $\frac{\infty}{\underset{J}{7}}$ & $\begin{array}{l}\infty \\
\mathscr{2} \\
\text { ○) } \\
\text { 이 }\end{array}$ & 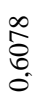 & $\begin{array}{l}\text { 足 } \\
\text { ㅇ } \\
\text { o }\end{array}$ & $\begin{array}{l}\text { ని } \\
\text { రి } \\
\infty \\
0\end{array}$ & $\begin{array}{l}\text { ते } \\
\text { ᄋ̆ } \\
\text { م. }\end{array}$ & \&̊ \\
\hline & 0,5 & $\begin{array}{l}\text { 슴 } \\
\text { तू } \\
0\end{array}$ & $\begin{array}{l}\hat{m} \\
\hat{m} \\
0^{\prime}\end{array}$ & 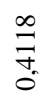 & $\begin{array}{l}\infty \\
\text { ᄋ } \\
\text { 유 } \\
\text { 이 }\end{array}$ & 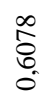 & 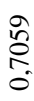 & 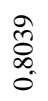 & 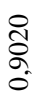 \\
\hline \multirow{2}{*}{0,5} & 1 & $\begin{array}{l}0 \\
\stackrel{-}{=} \\
0\end{array}$ & 슴 & $\stackrel{\hat{m}}{\tilde{n}}$ & $\frac{\infty}{\underset{J}{J}}$ & $\begin{array}{l}\infty \\
\stackrel{2}{\circ} \\
\text { 우 } \\
0\end{array}$ & $\begin{array}{l}\infty \\
\hat{0} \\
0 \\
0 \\
0\end{array}$ & $\begin{array}{l}\stackrel{\Omega}{0} \\
\text { 웅 } \\
0\end{array}$ & $\begin{array}{l}\text { ले } \\
\stackrel{0}{0} \\
\infty\end{array}$ \\
\hline & 0,5 & $\begin{array}{l}\mathscr{8} \\
\stackrel{\sigma}{0} \\
0 \\
0\end{array}$ & $\begin{array}{l}\frac{2}{2} \\
= \\
= \\
0\end{array}$ & $\begin{array}{l}\hat{N} \\
\stackrel{N}{0} \\
0\end{array}$ & $\begin{array}{c}\hat{m} \\
\hat{n} \\
0\end{array}$ & $\begin{array}{c}\infty \\
\underset{\sigma}{\exists} \\
\stackrel{+}{0}\end{array}$ & $\begin{array}{l}\text { ஜ } \\
\text { Oे } \\
\stackrel{1}{0} \\
0\end{array}$ & 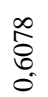 & 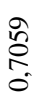 \\
\hline
\end{tabular}


For example, let us a value of estimated indicators will be as the vector $\mathrm{EI}=\{0,5 ; 0,5 ; 1 ; 1 ; 0,5\}$. Then the intermediate indicator of the component will equal 0,3137 .

Step 4.4. Therefore, the matrix of ranks can be built by the principle described above with the differentiation step $0,1(S=10)$ for increasing of an determination accuracy of the intermediate indicators of some components of the productivity of the enterprise activity. The following intermediate indicators such as economic, ecological, social and legal components can be determined by the estimated indicators and with the help of the normalized matrix of ranks for the following enterprises: Enterprise 1, Enterprise 2, Enterprise 3, Enterprise 4, Enterprise 5 and Enterprise 6 for the time period 2009-2013 (Table 5). In this case, the real enterprises were been depersonalized that some damage has not been inflicted to these enterprises, for example, their image or reputation.

Table 5. Economic, ecological, social, legal intermediate indicators of the components of the productivity activity for the considered above enterprises

\begin{tabular}{|c|c|c|c|c|c|c|c|}
\hline Components & Year & Enterprise 1 & Enterprise 2 & Enterprise 3 & Enterprise 4 & Enterprise 5 & Enterprise 6 \\
\hline \multirow{5}{*}{ Economic } & 2009 & 0,1013 & 0,1932 & 0,1022 & 0,0093 & 0,1222 & 0,0211 \\
\hline & 2010 & 0,2743 & 0,0202 & 0,1832 & 0,0566 & 0,0931 & 0,0111 \\
\hline & 2011 & 0,2014 & 0,1304 & 0,0922 & 0,0020 & 0,0931 & 0,0193 \\
\hline & 2012 & 0,3016 & 0,0020 & 0,0922 & 0,0111 & 0,1295 & 0,0120 \\
\hline & 2013 & 0,5474 & 0,0931 & 0,0002 & 0,1249 & 0,0002 & 0,0002 \\
\hline \multirow{5}{*}{ Ecological } & 2009 & 0,0002 & 0,0038 & 0,1003 & 0,1013 & 0,1495 & 0,1095 \\
\hline & 2010 & 0,1003 & 0,0193 & 0,1013 & 0,0220 & 0,1104 & 0,1013 \\
\hline & 2011 & 0,0912 & 0,0093 & 0,0912 & 0,0721 & 0,1003 & 0,1823 \\
\hline & 2012 & 0,1013 & 0,0220 & 0,1923 & 0,0184 & 0,1104 & 0,2023 \\
\hline & 2013 & 0,0931 & 0,0202 & 0,1022 & 0,0648 & 0,1022 & 0,1013 \\
\hline \multirow{5}{*}{ Social } & 2009 & 0,0011 & 0,0002 & 0,0184 & 0,3107 & 0,1195 & 0,0284 \\
\hline & 2010 & 0,0011 & 0,0202 & 0,0275 & 0,4746 & 0,0102 & 0,0266 \\
\hline & 2011 & 0,0102 & 0,0020 & 0,0457 & 0,4655 & 0,0193 & 0,0357 \\
\hline & 2012 & 0,0193 & 0,0002 & 0,0557 & 0,0011 & 0,4109 & 0,0093 \\
\hline & 2013 & 0,1104 & 0,0922 & 0,1013 & 0,0922 & 0,0466 & 0,1104 \\
\hline \multirow{5}{*}{ Legal } & 2009 & 0,0931 & 0,1850 & 0,1113 & 0,0002 & 0,0011 & 0,1295 \\
\hline & 2010 & 0,0931 & 0,0002 & 0,0931 & 0,0002 & 0,1859 & 0,2588 \\
\hline & 2011 & 0,0931 & 0,0002 & 0,1941 & 0,0821 & 0,1104 & 0,1213 \\
\hline & 2012 & 0,1850 & 0,0275 & 0,0002 & 0,2388 & 0,0366 & 0,2961 \\
\hline & 2013 & 0,2861 & 0,0011 & 0,2032 & 0,0275 & 0,0931 & 0,0912 \\
\hline
\end{tabular}

Therefore, the following conclusion can be made according to the Table 5, Enterprise 1 respectively became the best enterprise behind the level of the following economic (corresponding indicator is equal 0,5474) and legal (corresponding indicator is equal 0,2861) components of the productivity of the enterprise activity in 2013. Enterprise 3 has the best intermediate indicator of the following ecological (corresponding indicator is equal 0,1022) and social components. Enterprise 2 has the worst results on intermediate indicators of the ecological (corresponding indicator is equal 0,0202) and legal (corresponding indicator is equal 0,0011) components. The following Enterprise 3, Enterprise 5, Enterprise 6 have the lowest indicator of the economic component (corresponding indicator is equal 0,0002).

Step 5. The orthogonal reflection of some variants of the intermediate indicator's combinations of the economic, ecological, social, legal components of the productivity of the considered above enterprises activity can be executed in the plane in the set Rectangular System of Coordinates (RSC) for a calculation of the generalized indicator of the productivity of the enterprise activity. That is the geometrical interpretation of the obtained earlier results can be executed as some segments in the plane, where the coordinates of vertices can be determined by all pairs of the possible combinations of the productivity components (because RSC has been used). Because the quantity of the productivity components is equal $\mathrm{K}^{\mathrm{C}}=4$, then a quantity of all possible pair combinations taking into account transpositions will equal 24 (that is $12^{\text {th }}$ segments). Then, a distance between the determined earlier points (paired combinations of the productivity components) in RSC can be calculated by the following formula [6]:

$$
D=\sqrt{\left(x_{2}-x_{1}\right)^{2}+\left(y_{2}-y_{1}\right)^{2}}
$$

where $\mathrm{D}$ is the distance between the determined earlier points of all variants of the combinations for the intermediate indicators of the productivity components;

$\mathrm{x}_{1}, \mathrm{x}_{2}, \mathrm{y}_{1}, \mathrm{y}_{2}$ are the coordinates of some points (in our case, there are a value of the intermediate indicators of the productivity components).

For example, a calculation of those indicators for Enterprise 1 in 2013 is presented in Table 6.

Rule of a calculation of a median (because the geometrical interpretation has been used) can be used or applied to the obtained earlier set of segments (in our case, it is 12th segments) based on their length that will allow obtaining the generalized indicator of the productivity of the enterprise activity. 
Table 6. Calculation of the parameters of all variants of combinations for the intermediate indicators of some components for Enterprise 1 in 2013 (an example)

\begin{tabular}{|c|c|c|c|c|c|c|c|c|c|c|}
\hline Coordinates & $\mathrm{x}_{1}$ & $\mathrm{y}_{1}$ & 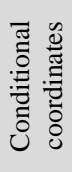 & $\mathrm{x}_{2}$ & $\mathrm{y}_{2}$ & 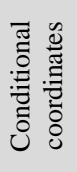 & $\left(\mathrm{X}_{2}-\mathrm{X}_{1}\right)$ & $\left(\mathrm{y}_{2}-\mathrm{y}_{1}\right)$ & $\left(\mathrm{x}_{2}-\mathrm{x}_{1}\right)+\left(\mathrm{y}_{2}-\mathrm{y}_{1}\right)$ & $\mathrm{D}$ \\
\hline 1 & 0,5474 & 0,0931 & 1,2 & 0,1104 & 0,2861 & 3,4 & 0,1910 & 0,0373 & 0,2283 & 0,4778 \\
\hline 2 & 0,0931 & 0,5474 & 2,1 & 0,1104 & 0,2861 & 3,4 & 0,0003 & 0,0683 & 0,0686 & 0,2619 \\
\hline 3 & 0,0931 & 0,5474 & 2,1 & 0,2861 & 0,1104 & 4,3 & 0,0373 & 0,1910 & 0,2283 & 0,4778 \\
\hline 4 & 0,5474 & 0,0931 & 1,2 & 0,2861 & 0,1104 & 4,3 & 0,0683 & 0,0003 & 0,0686 & 0,2619 \\
\hline 5 & 0,0931 & 0,1104 & 2,3 & 0,5474 & 0,2861 & 1,4 & 0,2064 & 0,0309 & 0,2373 & 0,4871 \\
\hline 6 & 0,0931 & 0,1104 & 2,3 & 0,2861 & 0,5474 & 4,1 & 0,0373 & 0,1910 & 0,2283 & 0,4778 \\
\hline 7 & 0,1104 & 0,0931 & 3,2 & 0,2861 & 0,5474 & 4,1 & 0,0309 & 0,2064 & 0,2373 & 0,4871 \\
\hline 8 & 0,1104 & 0,0931 & 3,2 & 0,5474 & 0,2861 & 1,4 & 0,1910 & 0,0373 & 0,2283 & 0,4778 \\
\hline 9 & 0,5474 & 0,1104 & 1,3 & 0,0931 & 0,2861 & 2,4 & 0,2064 & 0,0309 & 0,2373 & 0,4871 \\
\hline 10 & 0,1104 & 0,5474 & 3,1 & 0,0931 & 0,2861 & 2,4 & 0,0003 & 0,0683 & 0,0686 & 0,2619 \\
\hline 11 & 0,5474 & 0,1104 & 1,3 & 0,2861 & 0,0931 & 4,2 & 0,0683 & 0,0003 & 0,0686 & 0,2619 \\
\hline 12 & 0,1104 & 0,5474 & 3,1 & 0,2861 & 0,0931 & 4,2 & 0,0309 & 0,2064 & 0,2373 & 0,4871 \\
\hline
\end{tabular}

\section{Results of the Use of the Proposed Method}

Graphical mapping of the parameters of all options of the combinations of the intermediate indicators of some components for Enterprise 1 in 2013 is presented in Figure 2.

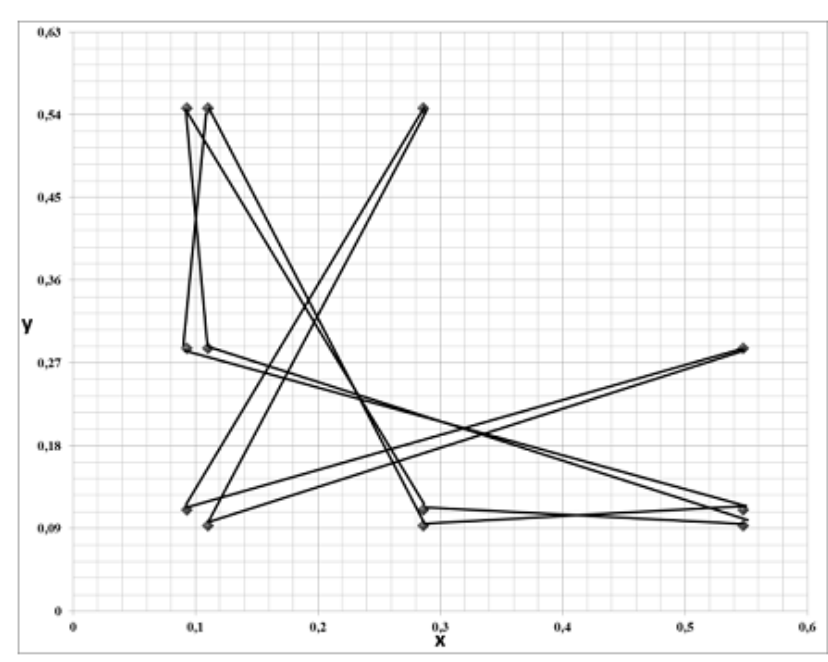

Figure 2. Graphical mapping of the parameters of all options of the combinations of the intermediate indicators of some components for Enterprise 1 in 2013

Median in the statistic is a set of values, which can be calculated as a mean of the ordered variation row. Thus, the median divides of this row on two equal parts: one part has a value variation attribute less, than an average value, and the second part has bigger value, than an average value. The median indicates to a value of a variation attribute, where a half of some units of a population has reached of this value of a variation attribute [5].

The median (unlike exponential average values) is the concrete characteristic of the variation row and it has certain values therefore it is still called as the descriptive characteristic. Median's such property is connected with that fact the individual deviations are repaid at the descriptive characteristic, as it can be for the averages values. Descriptive characteristics always match a certain variant [5]. This fact can be used for a median choice at definition of the generalizing indicator of the productivity of the enterprise activity. Dynamic changes of which is shown in Figure 3. The forecast for 2014 is shown in Fig. 4. The equation of some trend functions and value of a reliability of the approximation is shown in Table 7 . The generalizing indicators of the productivity of the enterprise activity are shown in Table 8.

Table 7. Equation of the trend functions and value of a reliability of the approximation of the enterprises

\begin{tabular}{|c|c|}
\hline Enterprise & Equation of a trend \\
\hline Enterprise 1 & $\mathrm{y}=0,0195 \mathrm{x}_{3}-117,81 \mathrm{x}_{2}+236850 \mathrm{x}-2 \mathrm{E}+08 ; \mathrm{R}_{2}=0,9674$ \\
\hline Enterprise 2 & $\begin{array}{c}\mathrm{y}=0,0391 \mathrm{x}_{4}-314,74 \mathrm{x}_{3}+949460 \mathrm{x} 2-1 \mathrm{E}+09 \mathrm{x}+6 \mathrm{E}+11 ; \\
\mathrm{R}_{2}=0,99\end{array}$ \\
\hline Enterprise 3 & $\begin{array}{c}\mathrm{y}=-0,0091 \mathrm{x}_{4}+73,234 \mathrm{x}_{3}-220901 \mathrm{x} 2+3 \mathrm{E}+08 \mathrm{x}-1 \mathrm{E}+11 ; \\
\mathrm{R}_{2}=0,99\end{array}$ \\
\hline Enterprise 4 & $\begin{array}{c}y=0,0032 x_{4}-25,921 x_{3}+78132 x 2-1 E+08 x+5 E+10 ; \\
R_{2}=0,99\end{array}$ \\
\hline Enterprise 5 & $\begin{array}{c}\mathrm{y}=-0,0448 \mathrm{x}_{4}+360,03 \mathrm{x}_{3}-1 \mathrm{E}+06 \mathrm{x}_{2}+1 \mathrm{E}+09 \mathrm{x}-7 \mathrm{E}+11 ; \\
\mathrm{R}_{2}=0,99\end{array}$ \\
\hline Enterprise 6 & $\begin{array}{c}y=-0,0442 x_{4}+355,81 x_{3}-1 E+06 x_{2}+1 E+09 x-7 E+11 ; \\
R_{2}=0,99\end{array}$ \\
\hline
\end{tabular}

Table 8. Generalizing indicators of the productivity of the enterprise activity

\begin{tabular}{|c|c|c|c|c|c|c|}
\hline Year & Enterprise 1 & Enterprise 2 & Enterprise 3 & Enterprise 4 & Enterprise 5 & Enterprise 6 \\
\hline 2009 & 0,1366 & 0,2647 & 0,0845 & 0,3179 & 0,1248 \\
\hline 2010 & 0,2066 & 0,0201 & 0,1165 & 0,4561 & 0,1366 \\
\hline 2011 & 0,1379 & 0,1287 & 0,1129 & 0,4014 & 0,2491 \\
\hline 2012 & 0,2600 & 0,0336 & 0,1647 & 0,2283 & 0,3145 \\
\hline 2013 & 0,4778 & 0,1166 & 0,1442 & 0,0883 & 0,1786 & 0,1082 \\
\hline
\end{tabular}




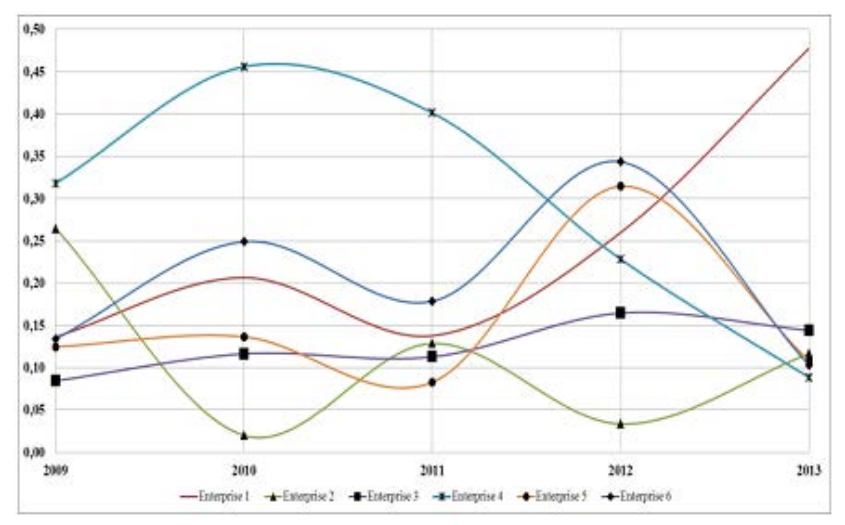

Figure 3. Dynamics of some changes (by years) for the generalizing indicator of the productivity of the enterprise activity

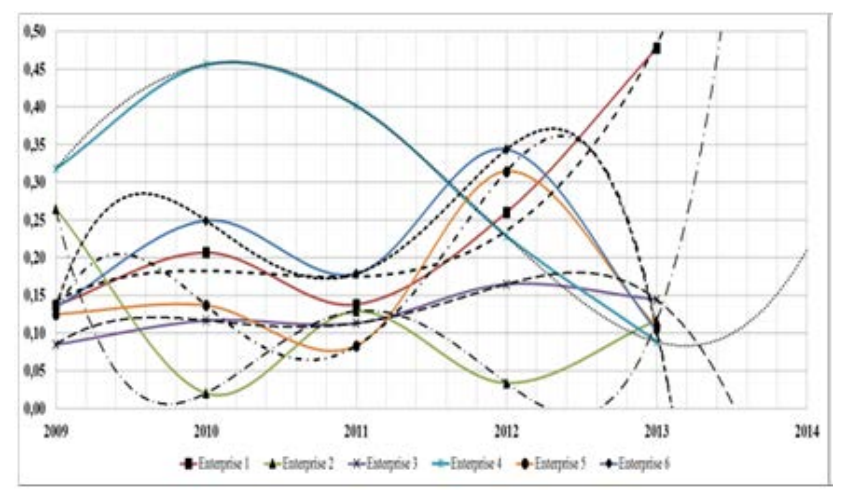

Figure 4. Forecast of the generalizing indicator of the productivity of the enterprise activity for 2014

\section{Conclusions}

Thus, the author's method of a calculation of the generalizing indicator of the productivity of the enterprise activity of the elected industry area was been developed based on the matrix-rank approach. The proposed technique allows receiving the numerical values of the generalizing indicator of the productivity of the enterprise activity due to use of the geometrical interpretation. In addition, use of this calculation method of the generalizing indicator of productivity of the enterprises activity for the elected industry area has approved on some indicators of the real enterprises (Table 5), which were been depersonalized that some damage has not been inflicted to these enterprises. Besides, the proposed technique has allowed creating practical conclusions of rather real enterprises of the elected industry area. Therefore, Enterprise 1 became the most productive enterprise in 2013 based on the generalizing indicator 0,4778 as it is shown in Figure 3 and Table 7. However, this result is rather mediocre, in view of that, the reference value of productivity of the enterprise activity is equal 1 . Ranges of admissible values cannot be determined with a sufficient accuracy based on that fact the generalizing indicator of the productivity of activity of the following Enterprises 16 did not exceed value 0,5 during all studied period.

Thus, the general conclusion can be formulated that the productivity of an activity of the studied enterprises of the elected industry area has the mediocre character and needs the relevant activities concerning its improvement.

\section{Acknowledgement}

The authors would like to thank the anonymous referees. In addition, the authors will be happy to answer for any requests or letters about this proposed method.

\section{References}

[1] Adhvaryu A., Nyshadham A. Health, Enterprise, and Labor Complementarity in the Household, The report, 2014. Available from:

http://www.anantnyshadham.com/storage/AN_Health

Enterprise_0314.pdf (checked 24.10.2014).

[2] Bagdonienė D., Simanavičienė A., Aimuntas G., "System of balanced sustainable development indicators: the case of SC TEO", Management theory and studies for rural business and infrastructure development, 1(25), 16-24, 2011. Available from: http://vadyba.asu.lt/25/16.pdf (checked 24.10.2014).

[3] Böttcher A. and Grudsky S.M., Toeplitz Matrices, Asymptotic Linear Algebra, and Functional Analysis, Birkhäuser, 2000.

[4] Darmits R. Z., "Communication of productivity and economic efficiency in system of management of the enterprise", the Scientific bulletin of NLTU of Ukraine, 20(12), 153-161, 2010.

[5] Davenport H. J., Economics of enterprise, Augustus M Kelley Pubs, 1913, 560.

[6] Deza, Elena; Deza, Michel Marie. Encyclopedia of Distances, Springer, 2009, 94.

[7] Druker P., The Practice of Management, HarperBusiness; Reissue edition, 2006, 416.

[8] Enterprise-Level Indicators for Resource Productivity and Pollution Intensity. A Primer for Small and Medium-Sized Enterprises. Version 1: November 2010. Available from: https://www.unido.org/fileadmin/user_media/Services/Green_Indu stry/Enterprise_Level_Indicators_for_Resource_Productivity_and \%20Pollution_Intensity.pdf (checked 24.10.2014).

[9] Fedulova L. I. Management of the organizations, 2004, 448.

[10] Gornostaeva J., Alekhina E., Kushnareva I., "Comparative analysis of efficiency of activity of service enterprises in Russia and the countries of Eastern Europe”, Review of Applied SocioEconomic Research, 7(1), 61, 2014.

[11] Gray M. Robert, Toeplitz and Circulant Matrices: A review, Cambridge University Press, London, 2009. Available from: http://ee.stanford.edu/ gray/toeplitz.pdf (checked 24.10.2014).

[12] Grygorenko G., Do privatized enterprises perform better than state-owned ones in Ukraine?, A thesis by Master of Arts in Economics, Economic Education and Research Consortium, 2001. Available from:

http://www.kse.org.ua/uploads/file/library/2001/ Grygorenko_Galyna.pdf (checked 24.10.2014).

[13] Kaplan R. S., Conceptual Foundations of the Balanced Scorecard, Working Paper 10-074, Harvard Business School, Harvard University, 2010. Available from: http://www.hbs.edu/faculty/ Publication\%20Files/10-074.pdf (checked 24.10.2014).

[14] Kavun S. V., "Hierarchical and matrix method of an assessment of level of economic security”, Bulletin of University of banking of National bank of Ukraine, 1(19), 265-271, 2014.

[15] Kavun S. V., "Mechanism of ranging of information with limited access”, Information security: Materials of scientific and practical conference, Ukraine, Kiev, 34-39, March 2009.

[16] Kavun S., "Indicative-geometric method for estimation of any business entity", International Journal of Data Analysis Techniques and Strategies, in press, 2014. Available from: http://www.inderscience.com/info/ingeneral/forthcoming.php?jcod e=ijdats (checked 24.10.2014).

[17] Kavun S., "Matrix model of system of economic security of business activity”, MSU Bulletin. Economic sciences, 10(2), 18-22, 2007.

[18] Korchevska L., Zhosan G. and Kavun S., "Social Responsibility as a Contextual Component of the Enterprise Economic Security”, Journal of Finance and Economics, 1(4), 95-104, 2013. Available from:

http://pubs.sciepub.com/jfe/1/4/6/index.html\# (checked 24.10.2014).

[19] Kosyanchuk F., Matsekh D., Statistic. The program of a course, examination and methodical instructions to its performance for 
students of economic specialties (second higher education), 2007 67

[20] Levchenko A. and Rudychev A., "Technique of the Complex Assessment of Business Activity of an Industrial Enterprise with JSC "Belgorodstroydetal" as an Example", World Applied Sciences Journal, 24(10), 1308-1315, 2013.

[21] Safin A. I., "Methodic of an assessment of social economic efficiency of regional industrial policy”, Expert, 14, 32-37, 2009.

[22] Serba S.V., "Role of industrial enterprise activity for the enterprise business plan”, Modern problems of science and education, 6, 2011, Available from: http://www.science-education.ru/pdf/2011/6/223.pdf

(checked 24.10.2014).

[23] Shershnyova Z., Strategic management, 2004, 699, Available from: http://buklib.net/component/option,com_jbook/task,view/ Itemid,36/catid,184/id,7983.

[24] Zhosan G. V., Trukhachova K.V., "Conceptual provisions of social responsibility of the enterprise as theoretical basis of the balanced productivity", National Khmelnytsky's Messenger of university. Economic sciences, 2(4), 247-254, 2013. 